\title{
The stock market capitalisation and financial growth nexus: an empirical study of western European countries
}

\author{
Faris Alshubiri ${ }^{*}$ (])
}

\begin{abstract}
This study aimed to analyse the stock market capitalisation and financial growth nexus of Western European countries from 1989 to 2018 in order to understand the interactive relationship between the stock market and the economy to identify the specific financial market channels through which economic growth is managed. The pooled least square findings identified positive significant relationships between stock market capitalisation, foreign direct investment and stocks traded and financial growth, while negative and significant relationships were found between GDP per capita growth and inflation and financial growth. The fixed effect, random effect and pooled mean group models yielded the same results, indicating positive significant relationships between stock market capitalisation and stocks traded and financial growth, while the effect of foreign direct investment on financial growth was positive and insignificant. Finally, there were negative and significant relationships between GDP per capita growth and inflation and financial growth. The results from the quantile regression (tau $=0.10,0.20,0.30,0.40$ and 0.50 ) there were positive relationships between stock market capitalisation and stocks traded and financial growth for all percentiles, while there were negative relationships between GDP per capita growth and inflation and financial growth except at the 0.30 percentile; foreign direct investment also had a negative relationship to financial growth at the 0.30 percentile. Most variables were significant at a $1 \%$ significance level. However, inflation was insignificant at the 0.10 percentile, foreign direct investment was insignificant at the $0.20,0.30,0.40$ and 0.50 percentiles, and stocks traded were insignificant at the 0.40 and 0.50 percentiles. All of the applied the diagnostic tests confirmed the robustness of the data. The main conclusion is that countries should minimise any regulatory obstacles to financial markets and protect the rights of shareholders. Furthermore, advanced financial systems should reduce the obstacles faced by companies in terms of external financing.
\end{abstract}

Keywords: Stock market capitalisation, Financial growth, Financial market theory, Financial institutions, Western Europe

JEL Classification: $\mathrm{O} 40, \mathrm{G} 10, \mathrm{GO}$

\section{Introduction}

Financial growth is the main driver in building the economy of a country where industrialisation reflects positive economic indicators and expected growth [1]. Financial

*Correspondence: falshubiri@du.edu.om

Department of Finance and Economics, College of Commerce

and Business Administration, Dhofar University, P.O. Box: 2509, 211 Salalah, Oman growth contributes to the stability of economic indicators, but research and development and appropriate technologies are needed to achieve success in accordance with global requirements [4]. The work established by Schumpeter [61] and developed by McKinnon [46] considered the causal relationship between the financial sector and economic growth. This growth moves resources from financial markets to production markets by providing financial surpluses from savings operations [5]. 
To explore indicators and evaluate an economy requires an understanding of the financial capital market indices, which are important for decision makers and policy makers [8]. Since continued research and development contributes to increases in industrialisation and thus the development of capital markets, the growth of the stock market leads to sustainable economic development [30]. The best stock indices indicate that enthusiastic and satisfied stakeholders help improve financial growth [11].

Investors are attracted to countries that are concerned with the growth of their economies, production stability; however, flexible plans can be developed that can easily adapt to financial growth [59]. Thus, investors can achieve better and faster profits in financial markets with a stable economy [30].

The relationship between the value of the stock market and financial growth is a turning point for economic growth as fluctuations in interest rates can contribute to investment changes that favour financial markets. However, investors try to diagnose associated risk ratios [17] and choose securities based on an understanding of the inherent risks. Given that the stock market carries high risks, assuming the achievement of high and fast profits compared to bank credit, extensive research is needed to judge the viability of securities. Banks issue certain financial instruments, such as savings certificates and treasury bills, to control interest rates and inflation levels [11]. Therefore, interest rate changes indirectly affect the performance of the stock market and are ultimately reflected in the overall economic development of the country [8].

Stiglitz [60] suggested that Keynes, in the general theory, indicated that investors are interested in profits in the short term rather than returns in the long run. This explains and consistent by a number of large companies, especially in the global financial crisis in 2007-2008 after the great collapse of the global financial markets [1]. Therefore, expecting a strong long-term positive relationship is not easy and poses a major challenge in most countries [4].

Although the investor's role is prominent on the demand side in Western European countries, structural problems may hinder the necessary development of these markets. The investment portfolios and investment funds highlighted the average growth of all variables in Western European countries, as shown in Fig. 1. All variables had constant growth except foreign investment, which fluctuated and increased in 1988-2000 and 2004-2006 and then decreased in 2014-2016. Gross domestic product (GDP) per capita growth (GDPPG) declined in 20072009 , increased by $1.38 \%$ in 2011 , decreased by $-0.61 \%$ in 2012 and increased by $2.8 \%$ in 2017 and $2.54 \%$ in 2018 .

In beginning of the 1990s, the growth in Western European countries was weak; the 1990s until the beginning of the global financial crisis in 2007 was considered a late period for Western European countries with productivity declines in light of the acceleration of American productivity. However, after the financial crisis of 2007, the emergence of globalisation and the growth of the telecommunications and technology sector, the European economy reached the limits of its growth and initiated developments, including challenges, as well as working on economic reforms. Western European countries began to develop in the context of European integration and expansion and tried to

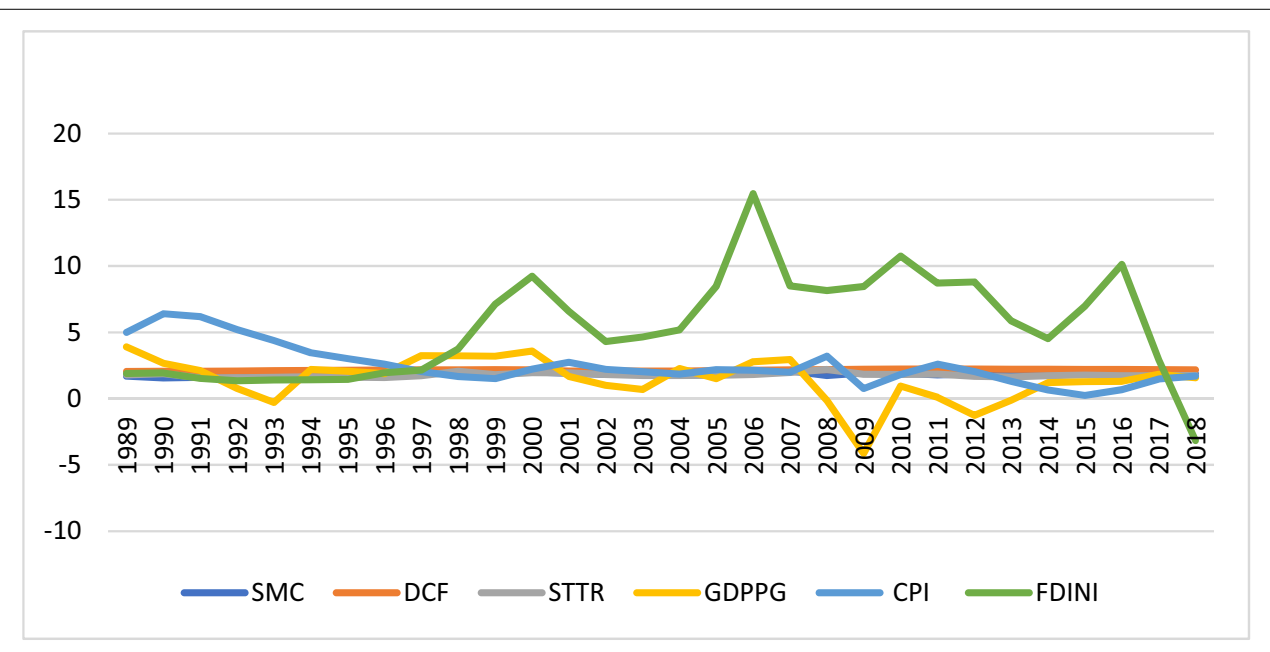

Source: World development indictors (2018)

Fig. 1 Average growth of variables in Western Europe 1989-2018. Source: World development indictors (2018) 
reduce the costs of trade to increase productivity, leading to a temporary impact on economic growth. European countries were distinguished by taxes and a lack of competition, while the rate of regulation was high; in the 1990s, they worked to emulate more economically advanced countries through reforms [65].

Western European countries are still at a low level of productivity according to the standards of productivity. Through the European Union, the most Western European countries improved their income and productivity levels and raised their GDP levels to reach $12 \%$ of the global average, while GDPPG reached four times the global average, and the market structure was adjusted so that governments were not encouraged to enter a market balance in terms of supply and demand, form a single market or increase their use of costly social protection reforms [65].

One of the reasons for the ambiguity in the literature relates to the size of the stock market and its relationship to financial development, as most studies use the stock market index to measure the impact of the development and growth of the stock market. The stock market index is not a suitable measure for the size of the stock market because the index moves according to the share price, especially for multinational companies, which clearly affects negatively on the share price. Moreover, the European market is concerned with small and medium companies, which are major engines for the financial market and have a prominent role in financial growth, relieving the pressure on workers and improving the economic structure. In addition, the method of selecting the stocks that constitute the financial market index, which is done through financial committees, may not be based on the changes created in the market.

Based on theoretical analysis and a review of relevant studies, there is a research gap in addressing the effects of the stock market and the extent of its impact on financial growth. Therefore, the current study aims to analyse the stock market capitalisation (SMC) and financial growth nexus in Western Europe over the period of 1989-2018 by assuming control variables. A statistical scientific methodology and a set of special tests were applied as robustness checks. The main purpose of this study was to determine the effect of the financial market within a group of Western European countries that have specific characteristics.

The rest of this paper is organised as follows: the literature is reviewed in the second section. The methodology, data and equations are presented in the third section, while the results are described in the fourth section. Finally, the conclusion and policy implications are shared in the fifth section.

\section{Literature review}

Economies of various strengths faced the global financial crisis of 2007-2008, but effects were more volatile in unstable financial markets. Thus, the bells of financial crisis rang in more volatile stock markets, and financial markets with low and less stable capabilities had to understand the value of capital market growth. Since macroeconomic research is a controversial topic, results differed according to the economic status of each country; however, researchers understand the importance of the results according to the characteristics of the different countries. Marques [41] stated that stock market growth has a causal and positive relationship with economic growth; he also noted that the Portuguese economy is small compared to other European countries, but stakeholders are always interested in investing in an economy that strives to grow.

Theoretical and applied studies were divided based on the relationship between the stock market and growth markets. Please note that researchers in previous studies also had results that could be divided into three parts as the following:

\section{Value of the stock market and growth nexus}

Devereux and Smith [21] and Obstfeld [50] emphasised the importance of the credit mechanism on financial growth and how liquidity positively impacts the development of the stock market, which, in turn, increases economic growth and productivity. In most developed countries, the theory of the development of financial markets supports an increase in economic growth. $\mathrm{Yu}$ et al. [69] and Atje and Jovanovic [2] found that results may differ based on the study methodology and sample used, but it is not identical to the effect that the money market in banks has on lending policy, which does not increase economic growth.

Levine and Zervos [38] indicated that stock liquidity and bank development positively contribute to forecasting growth, accumulating capital and improving the level of production in light of the presence of a supervisory role of economic units. In addition, we found that the size of the stock market and the changes that occur in prices are not compatible with international integration in economic growth. Boubakari and Jin [11] found that the stock markets and banks are important economic units in influencing economic growth, and Beck [6] indicated that investment in the financial sector has a long-term relationship with economic growth. In addition, the causal relationship between stock markets and growth has been rejected in small and illiquid stock markets. Furthermore, middle- and high-income levels contribute to a positive significant relationship between stock markets and 
economic growth [58]. Harris [31] found that emerging markets are associated with a weak relationship between the development of financial markets and growth.

Naceur and Ghazouani [48], Demirguc-Kunt and Levine [19] and Demirguc-Kunt et al. [20] pointed out that there is a moral relationship between the performance of banks and the stock market and that this relationship depends on the structure of the market level; in many cases, the financial market grows in parallel with the money market and is reflected in economic growth. However, the optimum capital structure that helps in the development of financial markets, as McGowan [42] noted, that stock growth depends on each stage of financial development. Cecchetti and Kharroubi [13] indicated that financial markets may undergo periods of low growth from financial development and that economic growth needs revitalisation processes from time to time through the integration of local financial resources. Rioja and Valev [56] demonstrated the positive and stable impact of the size of the money market performance on capital stock markets, with a weak relationship coinciding with low-income countries.

Francis and Ofori [26] pointed out that political circumstances play an important role in the development of financial markets, as development in an accessible market is considered relative since the capital changes from one period to another based on the economic conditions. Kaplan [34] and Cos, Kun and Umit [18] demonstrated that the Turkish financial market is in harmony with the booming economy in light of the increase in trading volume in the bond market and that this recovery contributes to increasing economic growth. Araç and Ozcan [4] and Karabıyık and ve Taşkın [35] found that bank assets play a prominent role in the development of money markets and positively contribute to the emergence of strong supply and demand in building the economy.

Babajide et al. [9] indicated that stock market evaluation results are strong and correlate morally with economic growth. One of the most important of this finding is that decision makers seek a deeper understanding of market conditions and characteristics in addition to the relationships between macroeconomic variables.

Consistent with Carpenter [17], Marques et al. [41] did not indicate a clear trend in the relationship between stock markets and economic growth, while Babajide et al. [9] argued its application in a study on the Chinese economy in which the growth of the stock market was a major long-term driver of growth. According to Barro [8], when stock market valuation levels decrease, the economy tends to stagnate. Fama [27] found that high levels of economic activity emerge from a negative relationship between the stock market and inflation. Given these mixed results, further studies in this field are needed.

\section{Components of the capital market and growth nexus}

Some studies analysed the components of financial markets by diagnosing various institutions based on the development of the financial markets. Ong and Sy [52] indicated that local investment cooperative funds significantly contribute to the development of local securities and stimulate the financial derivatives market and thus economic growth. Fink et al. [25] and Zandberg and Spierdijk [70] indicated that effective economic activity affects the bond market effectively and that changes in bond funds are more effective in the long term than in the short term. Mishra et al. [44] indicated that foreign investment funds positively contribute to local financial funds, leading to economic growth.

Bijlsma et al. [10] found that increasing the size of company assets for investors enhances the efficiency and effectiveness of financial markets; this is consistent with Pradhan et al. [54] found that the long-term effectiveness of financial markets and a major driver of market development. Mizen and Tsoukas [47] noted that improving liquidity, which has the largest role in issuing bonds, stimulates economic growth. Ayadi [5] emphasised, however, that GDP greatly affects the development of the stock market; in this study of Asian countries with large economies, Ayadi [5] pointed to a negative relationship between the liquidity of securities and the size of companies and indicated the need to adopt the decision maker regarding the economic policies after the growth of the stock market affects the state of the economy.

Using the Autoregressive Distributed Lag (ARDL) model, Faisal et al. [28] predicted a positive relationship between stock market development and foreign investment and a negative relationship between stock market development and financial development. In contrast, a long-term relationship was established between interest rates and stock prices by applying the current value model of shares and taking advantage of the discount rate. Zhou [71] pointed out that there is a long-term and significant relationship between the interest rate and the stock price and that increases in the prices of securities positively impact stock returns. In addition, dividend ratios contribute greatly to increasing the returns and prices of shares.

Maysami and Koh [45] used a vector error correction model (VECM) model to show that a long and balanced relationship between stock market prices and performance returns helps control the money supply in the market. In addition, they demonstrated that exchange and interest rates have a clear and positive effect on the control of the stock market, although this effect varies based on the available country resources. Gan et al. [29] found that the New Zealand stock price index is consistent with changes in interest rates, the money supply, and 
the level of GDP, as the stock index leads to changes in macroeconomic indicators. Kurihara [37] pointed out that there is no relationship between the interest rate and share prices in Japan but noted that the exchange rate has a positive impact on stock prices.

Ologunde et al. [51] found a negative correlation between the interest rate and the development of stock prices, especially government ones. Mahmudul and Gazi [43] identified a negative relationship between the interest rate and stock prices in most of their study sample, which was divided according to the availability of economic resources in the studied countries. Büyükşalvarcı [12] adopted an arbitrage model and found that the consumption index, the prices in the money market and the production index and the oil and exchange rates negatively impacted the financial market index in Turkey, while the money supply had a positive relationship with the financial market index.

Bijlsma et al. [10] noted that financial markets thrive when pensions are high because this reflects a positive impact on economic growth and that intermittent pension income has a negative impact during financial crises. According to Aramburo et al. [1], when borrowing is difficult and saving is at its lowest levels, investment becomes a difficult decision, affecting investments in financial markets, which negatively affects economic growth.

Weissteiner et al. [67] found that industrialised countries have a high GDP, which leads to an economic model characterised by innovation, as demonstrated by modern economic structures that can be relied upon in the economy. According to Heijdra et al. [30], social security contributions lead to the accumulation of capital, enabling the exploitation of these funds in the money market for securities; this is how the money is redistributed among individuals in society. However, Singh and Beetsma [59] demonstrated that monetary policy influences industrial sectors in terms of demand but differs in terms of prices; therefore, it is necessary to optimise the use of resources and allocate links to the demand for resources.

\section{Debt market and economic growth nexus}

According to the International Monetary Fund [32], judging institutions by the amount of their debt is not easy, the extent of the debt impacts economic growth and financial markets, as previous literature such as Schclarek [57] found a negative relationship due to an inverse $U$ curve between the debt ratio as a percentage of GDP and economic growth.

Reinhart and Rogoff [55] found a positive and weak relationship between government debt and GDP in developed and emerging countries. Kumar and Woo [36] and Checherita and Rother [14] found a nonlinear relationship between levels of debt and economic growth, and a high level of debt had a negative relationship with long-term growth. Panizza and Presbitero [53] and Clements et al. [15], who found that a rise in government debt reinforces the negative relationship to long-term growth. According to Dreger and Reimers [22], the negative relationship between debt and growth arises through a failure to adopt an appropriate debt ratio for each company. Fincke and Greiner [24] and Thumrongvit et al. [62] conducted a rigorous study that indicated a positive relationship between debt and growth but with a small correlation rate. Abbas and Christensen [3] and Nordin and Nordin [49] pointed out, however, that debt levels vary according to the potential inflation rates, identifying a positive effect between debt and economic growth.

Most of the previous studies attributed the total contribution of the capital market to financial growth. However, the present study attempts to bridge the research gap by addressing the following question: Does the capital stock market stimulate and highlight financial growth in Western European economies? they examined how the instability affected their economies and industrialisation process?

The literature review revealed inconsistent findings about the nature of the relationship between the stock market and the financial economy. The nature of the relationship may differ from one country to another according to the level of economic growth. Cultural and institutional factors can also influence the nature of the relationship between the stock market and the financial economy. As such, the present study aimed to diagnose the relationship between the stock market and financial development by using a strong methodology to examine a group of European countries that possess unified characteristics and test the hypotheses.

\section{Methods}

This section describes the data and equations used in the current study. Data from the World Development Indicators [65] were used for all of the variables in the current study. The data covered the period from 1989 to 2018 for 12 of the 17 Western European countries listed in the World Bank [66]: Austria, Belgium, France, Germany, Greece, Luxembourg the Netherlands, Norway, Portugal, Spain, Switzerland and the UK. Five Western European countries-Denmark, Finland, Iceland, Italy, Swedenwere not included because complete data were not available for this period.

The present study examines the stock market capitalisation (SMC) and financial growth nexus. The independent variable was an SMC proxy consisting of the SMC of listed domestic companies (\% of GDP); the financial growth proxy, as the dependent variable, was measured 
by the domestic credit provided by the financial sector (DCF) (\% of GDP). The study used four control variables: GDPPG (annual \%), inflation, consumer prices index (CPI) (annual \%), foreign direct investment net inflows (FDINI) (\% of GDP) and stocks traded, turnover ratio of domestic shares (STTR) (\%). The definitions of the variables are available in "Appendix A".

Panel data were used to test the hypotheses. The study's focus on the period between 1989 and 2018 and its focus on 12 out of 17 Western European countries can be considered limitations of this study, due to unavailable full information's of all variables of the study. The results are focused on Western Europe's regional financial markets growth. The economic growth in most of the institutions of these countries will lead to financial development. The main model regression equation for our variables is as follows:

$$
\begin{aligned}
D_{C F_{i, t}=} & \beta_{0}+\beta_{0} \text { Indepdent. }_{\text {Var }}, t \\
& +\beta_{0} \text { controlvaraibles } \\
i, t & +\varepsilon_{i, t}
\end{aligned}
$$

where $D C F_{i t}$ is the financial growth proxy, which measures the domestic credit by banking sector as a proportion of GDP of country $I$ at time $t$ as a dependent variable. The Indepdent. Var $_{i, t}$ is the SMC proxy measured by the SMC of listed domestic companies (\% of GDP). The four controlvariables $_{i, t}$ are GDPPG, STTR, CPI, and FDINI. The main hypothesis is formulated as follows:

$$
\begin{aligned}
\mathrm{DCF}_{\mathrm{it}}= & \alpha+\beta_{1} \sum_{i=1}^{n} \mathrm{SMC}_{\mathrm{it}}+\beta_{2} \sum_{i=1}^{n} \mathrm{CPI}_{\mathrm{it}} \\
& +\beta_{3} \sum_{i=1}^{n} \mathrm{FDINI}_{\mathrm{it}}+\beta_{4} \sum_{i=1}^{n} \mathrm{STTR}_{\mathrm{it}} \\
& +\beta_{5} \sum_{i=1}^{n} \mathrm{GDPPG}_{\mathrm{it}}+\varepsilon_{\mathrm{it}} .
\end{aligned}
$$

EViews 10 software was used to examine the hypotheses. The following robustness tests were used in this study: descriptive statistics; correlation matrix check; unit root tests with trends and without trends for Augmented Dickey-Fuller (ADF), Phillips-Perron (PP), ImPesaran-Shin (IPS), and Levin-Lin-Chu tests; pooled least square; fixed effect (FE); random effect (RE); correlated random effects; the Hausman test; quantile regression (tau $=0.10,0.20,0.30,0.40$, and 0.50$)$ and diagnostic tests, such as endogeneity, Wald, variance inflation factor, normality, and heteroskedasticity tests.

The descriptive statistics were applied after the check of the correlation matrix, which is defined as follows:

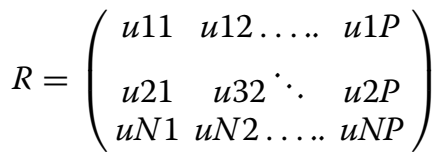

$$
\begin{aligned}
& R j k=S j k / S j S k=\sum_{r=1}^{n}(U i j-\overline{U j})(U i k-\overline{U k}) \\
& / \sqrt{\sum_{r=1}^{n}(U i j-\overline{U j})^{2}} \sqrt{\sum_{r=1}^{n}\left(U i k-(U k)^{2}\right.}
\end{aligned}
$$

where $R_{j}=$ correlation coefficient, $b / w, X_{j}$, and $X_{k}$.

Then, three-unit root tests were run. The most popular test for panel data among empirical researchers is the Levin-Lin-Chu unit root test $[39,40]$. ADF and PP tests are accepted as having less power for examining the unit root from a stationary variable. Based on a single time series, panel data unit root tests are an appropriate way to conduct unit root tests. Levin and Lin [39] developed the main model of unit root tests as follows:

$$
\begin{aligned}
& \delta y_{i, t}=p y_{i, t}-1+\alpha_{0}+\delta_{t}+\alpha_{i}+\theta_{t}+\varepsilon_{i, t} \ldots i=1.2 .3 .4 \ldots N, \\
& t=1,2,3,4 \ldots T
\end{aligned}
$$

This model includes individual and time trend effects. First, to order the serial correlation, we included lagged first differences in the ADF test. The limited distributions present the number of lags per the sample size. All cases in Levin and Lin's model refer to limited distributions as $\mathrm{N}$ and $\mathrm{T}$. The model is also measured by a pooled regression model of individual series and normalised disturbances using the $\mathrm{ADF}$ test, as follows:

$$
\Delta y i, t=p i y i, t-1+\sum_{j=1}^{p i} \phi i j \Delta y i, t-j+\alpha i+\varepsilon i, t
$$

There are two regressions of $\Delta y_{i, t}$ and $p_{i} y_{i, t-1}$ on the remaining variables, and the residuals are expressed by $e_{i, t}$ and $V_{i, t-1}$, respectively. Next, we regress $e_{i, t}$ on $V_{i, t-1}$ :

$$
e_{i, t}=p i V_{i, t-1}+\varepsilon_{i t}
$$

Due to the heteroskedasticity found in $\varepsilon_{i t}$, while the ordinary least square (OLS) refers to the $F_{i}$ estimator of fi in (1) directly, they suggest the following normalisation to control it:

$$
\begin{aligned}
& \hat{o} 2 e i=1 / T-F i-1 \sum_{t=f i+2}^{T}\left(e_{i, t}-F_{i} V_{i, t-1}\right) 2 \\
& e_{i, t}=e_{i, t} / o ́ e i
\end{aligned}
$$




$$
V_{i, t-1}=V_{i, t-1} /{ }^{o} e i
$$

The $e_{i, t}$ will be i.i.d. for all individual $i$. The $p 1=p 2=p n$ under $\mathrm{H} 1$ refers to IPS. Then, we take model $\Delta y_{i, t}=$ $p_{i} y_{i, t-1}+\alpha_{i}+\varepsilon_{i, t}$, Ho: $p=0, \alpha_{i}=0$ for all $i$ in Levin and Lin, and substitute $p i$ for $p$.

As shown, this model has a regression with trend and cross-sectional units that refer to N. Due to this issue, we used unit root tests instead of $\mathrm{T}$ observations in the pooling test. We let $\mathrm{ti}, \mathrm{T}(\mathrm{i}=1,2, \ldots, \mathrm{N})$, while let $\mathrm{E}(\mathrm{ti}, \mathrm{T})=\mu$ and $\mathrm{V}(\mathrm{ti}, \mathrm{T})=\mathrm{o}^{2}$. Then:

$$
\sqrt{N}(\bar{t} N, T-\mu) / o, N(0,1), \quad \text { where, } \bar{t}, N, T=1 / N \sum_{J=1}^{N} t_{I, T}
$$

The difference between the ADF and PP tests is considered in terms of the serial correlation and heteroskedasticity errors. ADF used the autoregressivemoving-average (ARMA) structure of errors as a parametric autoregression, while the PP test corrected this issue by an omitted autocorrelation. These modified statistics, named $Z_{t}$ and $Z \delta$, are given by:

$$
\begin{aligned}
& Z t=\sqrt{\left(\hat{o}^{2} / \lambda^{2}\right) t_{\tilde{\alpha}}}-1 / 2\left(\left(\lambda^{2}-\delta^{2}\right) / \lambda^{2}\right)\left(T(S E(a 0)) / \hat{o}^{2}\right) \\
& \left.\left.Z_{\delta}=T \tilde{\alpha}-1 / 2\right) T^{2}\left(\operatorname{SE}\left(a_{0}\right)\right) / o^{2}\right)\left(\lambda^{2}-o^{2}\right)
\end{aligned}
$$

The variance parameters estimator is under the terms $o^{2}$ and $\lambda^{2}$ :

$$
\dot{o}^{2}=\lim _{T \leftarrow \infty} T-1 \sum_{t=1}^{T} E\left(\varepsilon_{t}^{2}\right) \quad \lambda^{2}=\lim _{T \rightarrow \infty} \sum_{t=1}^{T} E\left(1 / T \sum_{t=1}^{T} \varepsilon_{t}^{2}\right)
$$

Under $H_{0}: \alpha_{0}=0$, the PP $Z_{\mathrm{t}}$ and $Z \alpha_{0}$ have the same distributions as the normalised bias and the Dickey Fuller (DF $t$-statistic). The panel data used in the current study are useful for comparing the performance of units (here, countries). This will be included in the time series data and cross section. The main model is estimated as follows:

$$
Y_{i t}=a Y_{i t-1}+\beta X_{i t}+u_{i t}
$$

where $Y_{i t}$ and $Y_{i t-1}$ represent the dependent variable; the lag of this variable under $I$ refers to countries and $t$ refers to years, while $X_{i t}$ represents exogenous variables, and $u_{i t}$ represents random error. The OLS is usually biased. Heterogeneity and endogeneity are the most common issues in the panel, and the OLS is referred to as coefficients for the intercepts and the slopes [68]. We referred to the orthogonality of the error term and ignored all individually specific effects, as the main assumption of OLS estimation. To avoid the pooled regression issue, we used FE and RE. A large number of observations can be applied to the panel data with more heterogeneity and less multicollinearity among the variables. Furthermore, we kept track of each unit of observation. Since time cannot change, we eliminated variables to solve the problem of omitted variables. However, there was heterogeneity in the panel data, which can be a disadvantage if the qualities of a country are not observable, leading to errors associated with inconsistent OLS observations.

The main assumptions for the FE model are included in the following equations:

$$
Y_{i t}=a Y_{i t}-1+\beta X_{i t}+\varepsilon_{i t}
$$

Assume that $\varepsilon_{\mathrm{it}}=\mathrm{V}_{\mathrm{i}}+\mathrm{u}_{\mathrm{it}}$; hence,

$$
Y_{i t}=a Y_{i t}-1+\beta X_{i t}+V_{i}+{ }_{i t}
$$

Two parts of the error $\varepsilon_{i t}$ : random as $u_{i t}$ this shows that $\left(\varepsilon_{i t}=V_{i}+u_{i t}\right)$ as OLS, fixed constant for each country $V_{i}$. The random estimation has the same specification as the FE except that $V_{i}$, the country constant, is fixed over time as a random variable with mean $E\left[V_{i}\right]$ and VAR $\left(V_{i}\right) \neq 0$. $V_{i}$ is a random term, and FE is less efficient and more consistent than RE. Thus, the model is as follows:

$$
Y_{i t}=a Y_{i t}-1+\beta X_{i t}+V_{i}+{ }_{i t}
$$

The regression technique ignores a regressor's impact for a whole distribution of the dependent variable and is affected by outliers. Hence, a quantile regression was used as a further robustness check for outliers and heavytailed distributions. Quantile regressions focused on the dependent variable of the conditional distribution [16]. The characteristics of predicting refer to Qt. $y / x$ and preserving Qt. $y / x$ under a transformation of quantile regression. The main quantile regression model is as follows:

$$
W_{i}=\beta_{0}+\beta_{1} s_{i 1}+\beta_{2} s_{i 2}+\beta_{p} s_{p}+\dot{\epsilon}_{i}, \quad i=1 \ldots n
$$

The response is $W_{i}$, and $i_{\text {th }}$ is the continuous observation. The predictors $s_{i 1}, \ldots, s_{i p}$ represent the main effects. To solve the problem of the OLS, we estimated the $Z_{j}$ :

$$
\min Z_{0}-Z p=\sum_{i=1}^{n}\left(Y i-Z_{0}-\sum_{i=1}^{n} X i j Z_{j}\right)^{2}
$$

In contrast, the quantile response level $t$ is as follows:

$$
\begin{aligned}
& Q_{T}\left(Y_{i}\right)=\beta_{0(t)}+\beta_{1(t)} s_{i 1}+\beta_{2} s_{i 2}+\beta_{p(t)} s_{p}+\dot{\epsilon}_{i}, \\
& \quad i=1 \ldots N
\end{aligned}
$$

while $Z_{j(t)}$ is estimated by solving the minimisation problem:

$$
\min Z_{0}-Z p_{(t)}=A_{t} \sum_{i=1}^{n}\left(Y i-\beta_{0(t)}-\sum_{i=1}^{n} X i j Z_{j(t)}\right)^{2}
$$


where $A_{t}(r)=t \max (r, 0)+(1-r) \max (-r, 0)$. The function refers to check loss $P_{t}(r)$ because its shape resembles a check mark. To increase robustness, the study used PMG dynamic panel data estimator. This estimator examined the relationships between SMC and DCF in the 12 selected European countries. Due to the homogenous data in each country, this estimator was used to restrict the same long-run coefficients. Then, short-run coefficients and error variances in all countries were run.

In this study, we used the following main formula:

$$
\begin{aligned}
& \mathrm{DCF}_{10,20,30,40,50 \mathrm{it}} \\
& =\alpha+\beta_{110,20,30,4050} \sum_{i=1}^{n} \mathrm{SMC}_{i t} \\
& +\beta_{210,20,30,4050} \sum_{i=1}^{n} \mathrm{CPI}_{i t}+\beta_{310,20,30,4050} \sum_{i=1}^{n} \mathrm{FDINI}_{i t} \\
& \quad+\beta_{410,20,30,4050} \sum_{i=1}^{n} \mathrm{STTR}_{i t}+\beta_{510,20,30,4050} \sum_{i=1}^{n} \mathrm{GDPPG}_{i t} \\
& \quad+\mathrm{U}_{10,20,30,4050 \mathrm{it} .}
\end{aligned}
$$

where DCF, SMC, CPI, FDINI, STTR, and GDPPG as explained in the methodology; $i$ refers to the industry sector, $t$ refers to time, $U_{i t}=\mu_{i t}+\varepsilon_{i t}, \mu_{i t}$ refers to unobservable individual effects, and $\varepsilon_{i t}$ is the error term. The choice of variables is based on the industrial revolution in Western Europe, which required the diagnosis of the state of financial markets and the ways in which they contribute to financial growth. The market value of the stock market was chosen as an indicator to measure the performance of the financial market and its impact on financial growth through domestic credit, which is the main driver of economic activity. The relationship between the variables was controlled by assuming the most common control variables, such as inflation, GDP and trading volume, as well as the participation of foreign investment in the GDP. These variables are dynamic in controlling the main model of the current study.

\section{Results and discussion \\ Descriptive statistics}

This study used descriptive statistics to show the mean, medium, minimum, and maximum, as presented in Table 1. The 12 selected Western European countries yielded 360 observations during the period of 1989-2018.

\section{Correlation matrix}

DCF is presented as the dependent variable in Table 2. The correlation of the explanatory variables is shown in the coefficients among the set of regressors employed in the empirical models. The correlation signals are consistent with the general theory, indicating that the DCF is positively correlated with FDINI (0.17), SMC (0.35), and STTR $(0.11)$ and negatively correlated with CPI $(-0.21)$ and GDPPG $(-0.14)$. The $t$-value is significant in Table 2 , as the absolute value of the $t$-statistics is more than 2 . The $r$ refers to the strength between the variables [23]. Regarding the effect size of the correlations, there are very weak (0.00-0.19) and weak (0.10-0.39) correlations between the variables, making it appropriate to run a regression. There is no multicollinearity between the two variable predictors, as shown by the correlations of this first order.

\section{Unit root tests}

To avoid spurious regression, we ran three different unit root tests, as shown in Table 3. The characteristics of all variables should be checked before running any tests. The unit root tests show individual intercept with trend and without trend. This study used many tests to examine the stationarity of variables. In the unit root tests, all variables were stationary due to the accepted null hypotheses, and the means of all variables were integrated at level $1(0)$ and $1(1)$. Hence, we were able to run the OLS model

\begin{tabular}{|c|c|c|c|c|c|c|}
\hline & CPI & DCF & FDINI & GDPPG & SMC & STTR \\
\hline Mean & 2.510 & 142.9 & 5.349 & 1.464 & 74.12 & 63.91 \\
\hline Median & 2.112 & 137.0 & 2.150 & 1.627 & 60.95 & 51.23 \\
\hline Maximum & 20.43 & 250.4 & 86.58 & 8.735 & 326.3 & 694.4 \\
\hline Minimum & -1.736 & 55.74 & -58.32 & -8.997 & 1.191 & 0.124 \\
\hline Std. Dev & 2.540 & 38.61 & 11.84 & 2.179 & 55.75 & 59.74 \\
\hline Skewness & 3.501 & 0.458 & 2.795 & -0.844 & 1.517 & 4.509 \\
\hline Kurtosis & 20.31 & 3.030 & 19.53 & 5.886 & 5.487 & 40.08 \\
\hline Observations & 360 & 360 & 360 & 360 & 360 & 360 \\
\hline
\end{tabular}
using the pooled least squares, FE and RE models and the quantile regression with no spurious results with regard to unit root effects.

Table 1 Descriptive statistics. Source: Software of E-views 10 output 
Table 2 Correlation matrix. Source: Software of E-views 10 output

\begin{tabular}{|c|c|c|c|c|c|c|}
\hline & CPI & DCF & FDINI & GDPPG & SMC & $\overline{\text { STTR }}$ \\
\hline \multicolumn{7}{|l|}{ CPI } \\
\hline Coefficient & 1.000 & & & & & \\
\hline t-test & - & & & & & \\
\hline Sig & - & & & & & \\
\hline \multicolumn{7}{|l|}{ DCF } \\
\hline Coefficient & -0.215 & 1.000 & & & & \\
\hline t-test & -4.170 & - & & & & \\
\hline Sig & 0.000 & - & & & & \\
\hline \multicolumn{7}{|l|}{ FDINI } \\
\hline Coefficient & -0.085 & 0.171 & 1.000 & & & \\
\hline t-test & -1.619 & 3.289 & - & & & \\
\hline Sig & 0.106 & 0.001 & - & & & \\
\hline \multicolumn{7}{|l|}{ GDPPG } \\
\hline Coefficient & 0.027 & -0.142 & -0.035 & 1.000 & & \\
\hline t-test & 0.511 & -2.720 & -0.674 & - & & \\
\hline Sig & 0.609 & 0.006 & 0.500 & - & & \\
\hline \multicolumn{7}{|l|}{ SMC } \\
\hline Coefficient & -0.244 & 0.352 & 0.154 & 0.076 & 1.000 & \\
\hline t-test & -4.774 & 7.129 & 2.958 & 1.448 & - & \\
\hline Sig & 0.000 & 0.000 & 0.003 & 0.148 & - & \\
\hline \multicolumn{7}{|l|}{ STTR } \\
\hline Coefficient & -0.078 & 0.116 & -0.014 & 0.025 & -0.089 & 1.000 \\
\hline t-test & -1.486 & 2.225 & -0.282 & 0.483 & -1.705 & - \\
\hline Sig & 0.137 & 0.026 & 0.777 & 0.6292 & 0.088 & - \\
\hline
\end{tabular}

Table 3 Augmented Dickey-Fuller and Phillips-Perron tests are a unit root test. Source: Software of E-views 10 output

\begin{tabular}{|c|c|c|c|c|c|c|c|c|}
\hline \multirow[t]{2}{*}{ Variable } & \multicolumn{2}{|c|}{ Individual intercept } & \multicolumn{2}{|c|}{ Individual intercept and trend } & \multicolumn{2}{|c|}{ Individual intercept } & \multicolumn{2}{|c|}{$\begin{array}{l}\text { Individual intercept and } \\
\text { trend }\end{array}$} \\
\hline & $\begin{array}{l}\text { ADF-Fisher Chi- } \\
\text { square (sig) }\end{array}$ & Order & $\begin{array}{l}\text { ADF-Fisher Chi- } \\
\text { square (sig) }\end{array}$ & Order & $\begin{array}{l}\text { PP_Fisher Chi- } \\
\text { square } \\
\text { (sig) }\end{array}$ & Order & \multirow{2}{*}{ 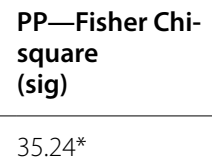 } & Order \\
\hline DCF & $34.41^{*}$ & $1(0)$ & $82.05^{* * *}$ & $1(1)$ & $201.9 * * *$ & $1(1)$ & & $1(0)$ \\
\hline SMC & $35.26^{*}$ & $1(0)$ & $145.38^{* * *}$ & $1(1)$ & $43.29^{* * *}$ & $1(0)$ & $33.54^{*}$ & $1(0)$ \\
\hline GDPPG & $96.66^{* * *}$ & $1(0)$ & $76.14^{* * *}$ & $1(0)$ & $113.5^{* * *}$ & $1(0)$ & $92.06^{* * *}$ & $1(0)$ \\
\hline $\mathrm{CPI}$ & $88.58^{* * *}$ & $1(0)$ & $60.66^{* * *}$ & $1(0)$ & $89.99^{* * *}$ & $1(0)$ & $63.77^{* * *}$ & $1(0)$ \\
\hline FDINI & $53.41^{* * *}$ & $1(0)$ & $39.19^{* *}$ & $1(0)$ & $110.6^{* * *}$ & $1(0)$ & $86.84^{* * *}$ & $1(0)$ \\
\hline STTR & $73.38^{* * *}$ & $1(0)$ & $54.77^{* * *}$ & $1(0)$ & $90.43^{* * *}$ & $1(0)$ & 71.01 & $1(0)$ \\
\hline \multicolumn{9}{|c|}{ Im, Pesaran, and Shin is a unit root test } \\
\hline & & \multicolumn{3}{|c|}{ Individual intercept } & & \multicolumn{3}{|c|}{ Individual intercept and trend } \\
\hline Variable & & \multicolumn{2}{|c|}{ Im, Pesaran, and Shin W-stat (sig) } & Order & & \multicolumn{2}{|c|}{ Im, Pesaran, and Shin W-stat (sig) } & Order \\
\hline DCF & & $-1.404^{*}$ & & $1(0)$ & & $-6.23^{* * *}$ & & $1(1)$ \\
\hline SMC & & $-2.298^{* *}$ & & $1(0)$ & & $-11.0^{* * *}$ & & $1(1)$ \\
\hline GDPPG & & $-6.958^{* * *}$ & & $1(0)$ & & $-5.62^{* * *}$ & & $1(0)$ \\
\hline $\mathrm{CPI}$ & & $-6.554^{* * *}$ & & $1(0)$ & & $-4.46^{* * *}$ & & $1(0)$ \\
\hline FDINI & & $-3.745^{* * *}$ & & $1(0)$ & & $-2.03^{* *}$ & & $1(0)$ \\
\hline STTR & & $-5.057^{* * *}$ & & $1(0)$ & & $-3.35^{* * *}$ & & $1(0)$ \\
\hline
\end{tabular}




\section{Panel pooled OLS regression}

The first tests conducted in this study were the pooled OLS estimations. Table 4 shows a significant and positive relationship between the SMC proxy and the financial growth proxy at a $1 \%$ level of significance. A $1 \%$ increase in SMC led to a 0.232increase in the DCF. At the same time, the impacts of FDINI and STTR on the DCF were positive and significant at $5 \%$ and $1 \%$, respectively. One percent increases in FDINI and STTR led to 0.347 and 0.093 increases in the DCF, respectively. Finally, the impacts of GDPPG and CPI on the DCF were negative and significant at $1 \%$ and $5 \%$, respectively. One percent increases in GDPPG and CPI led to 2.920 and 1.647 decreases in the DCF, respectively.

The model was robust, and the $F$-statistic was significant, meaning that the model was appropriate for predictions. These results are consistent with Levine and Zervos [38]; meanwhile, Boubakari and Jin [11] and Beck [6] indicated that investments and liquidity are two factors that positively affect long-term financial and economic growth by accumulating capital. McGowan [42], Cecchetti and Kharroubi [13] and Rioja and Valev [56] mentioned that the financial stage of the industry and the stability of the money market positively affect the capital stock market, enhancing financial growth. During financial crises, many economic indicators have been negatively affected, such as GDP [7]. Francis and Ofori [16]; Kaplan [34]; and Cos, Kun, and Umit [18] focused on how political circumstances and economic activities play a vital role in increasing the GDP and stock trading volume of financial markets.

Table 4 Penal OLS regression. Source: Software of E-views 10 output

\begin{tabular}{lllcl}
\hline Variables & Coefficient & Std. error & $\boldsymbol{t}$-value & Slg \\
\hline Constant & 126.3 & 4.762 & 26.52 & $0.000^{* * *}$ \\
SMC & 0.232 & 0.034 & 6.697 & $0.000^{* * *}$ \\
GDPPG & -2.920 & 0.847 & -3.448 & $0.000^{* * *}$ \\
CPI & -1.647 & 0.750 & -2.194 & $0.029^{* *}$ \\
FDINI & 0.347 & 0.157 & 2.209 & $0.027^{* *}$ \\
STTR & 0.093 & 0.031 & 3.002 & $0.002^{* * *}$ \\
$R^{2}{ }^{2}$ & 0.200 & & & \\
Adjusted $R^{2}{ }^{2}$ & 0.188 & & & \\
F-value & 17.70 & & & \\
sig(F-value) & 0.000 & & & \\
Observations & 360 & & & \\
Cross sections included & 12 & & & \\
\hline
\end{tabular}

Standard errors in parentheses ${ }^{* * *} p<0.01,{ }^{* *} p<0.05,{ }^{*} p<0.1$, in all the models of the current study, the dependent variable is the DCF

\section{Panel fixed effect}

The pooled OLS estimations did not consider the heterogeneity problem between the variables. Hence, an FE/ RE model was run to control this issue. The Hausman test determines which test is appropriate. The FE results confirmed the results of the pooled OLS for all signals and were significant except that the effect of FDINI on the DCF was insignificant. Table 5 indicates a significant and positive relationship between the SMC proxy and the financial growth proxy at a $1 \%$ level of significance. A $1 \%$ increase in SMC led to a 0.166 increase in the DCF. At the same time, the impact of FDINI on the DCF was positive and insignificant, while STTR was positive and significant at $1 \%$. One percent increases in FDINI and STTR led to 0.089 and 0.050 increases in the DCF, respectively. Finally, the impact of GDPPG and CPI on the DCF was negative and significant at $1 \%$ and $5 \%$, respectively. One percent increases in GDPPG and CPI led to 3.496 and 2.739 decreases in the DCF, respectively. It is worth noting that there was a robust as a whole model by F-statistic was significant, which means that, in general, the model was acceptable and could be used for predictions.

\section{Panel cross-sectional random effects}

The RE model also supports the solving of the heterogeneity between the panels. The RE results confirmed the FE results for all signals and were significant for all of the pooled OLS results except that the effect of FDINI on the DCF was insignificant. Table 6 shows the significant and positive relationship between the SMC proxy and the financial growth proxy at a $1 \%$ level of significance. A $1 \%$ increase in SMC led to a 0.173 increase in the DCF. At the same time, the impact of FDINI on the DCF was positive and insignificant, while STTR was positive and insignificant at $1 \%$. One percent increases in

Table 5 Penal fixed effect. Source: Software of E-views 10 output. The dependent variable is the DCF

\begin{tabular}{lllcl}
\hline Variables & Coefficient & Std. error & $\boldsymbol{t}$-value & Sig \\
\hline Constant & 138.8 & 4.294 & 32.33 & $0.000^{* * *}$ \\
SMC & 0.166 & 0.042 & 3.926 & $0.000^{* * *}$ \\
GDPPG & -3.496 & 0.610 & -5.725 & $0.000^{* * *}$ \\
CPI & -2.739 & 0.571 & -4.793 & $0.000^{* * *}$ \\
FDINI & 0.089 & 0.121 & 0.741 & 0.459 \\
STTR & 0.050 & 0.025 & 2.026 & $0.043^{* *}$ \\
$R^{-}{ }^{2}$ & 0.617 & & & \\
Adjusted $R^{2}{ }^{2}$ & 0.600 & & & \\
F-value & 34.66 & & & \\
sig(F-value) & 0.000 & & & \\
Observations & 360 & & & \\
Cross sections included & 12 & & & \\
\hline
\end{tabular}


FDINI and STTR led to 0.101 and 0.052 increases in the DCF, respectively. Finally, the impact of GDPPG and CPI on the DCF was negative and significant at $1 \%$ and $5 \%$, respectively. One percent increases in GDPPG and CPI led to 3.482 and 2.694 decreases in the DCF, respectively. It is worth noting that there was as a whole model by the F-statistic was significant, which means that, in general, the model was acceptable and could be used for predictions. These results are consistent with Ayadi [5]; however, Weissteiner et al. [67] emphasised that GDP greatly affects the development of the stock market. Many studies show that changes in the interest rates of the money market positively affect financial growth [29, 69]. Furthermore, Büyükşalvarcı [12] showed that the consumption index and the production index negatively impact the financial markets index, which is consistent with the CPI and growth nexus in the current study. Schclarek [57] referred to the inverse $U$ curve and found a negative relationship between the debt ratio of GDP and economic growth.

\section{Test cross-sectional random effects}

Table 7 shows that the Hausman test had an insignificant result, indicating that the null hypothesis strongly accepted the RE test as a suitable model for this study. To identify which estimator was correct, the WuHausman test was conducted. This test was explained by Johnston and Dinardo [33] as $H=\left(\dot{\mathrm{B}}_{\mathrm{RE}}-\dot{\mathrm{B}}_{\mathrm{FE}}\right)$ $\left(\sum_{\mathrm{FE}}-\sum_{\mathrm{RE}}\right)-1\left(\dot{\mathrm{B}}_{\mathrm{RE}}-\dot{\mathrm{B}}_{\mathrm{FE}}\right)$.

Table 6 Method: PANEL EGLS (cross-sectional random effects). Source: Software of E-views 10 output. The dependent variable is the DCF

\begin{tabular}{lllll}
\hline Variables & Coefficient & Std. error & t-value & Sig \\
\hline Constant & 138.0 & 7.807 & 17.67 & $0.000^{* * *}$ \\
SMC & 0.173 & 0.040 & 4.246 & $0.000^{* * *}$ \\
GDPPG & -3.482 & 0.609 & -5.712 & $0.000^{* * *}$ \\
CPI & -2.694 & 0.569 & -4.729 & $0.000^{* * *}$ \\
FDINI & 0.101 & 0.120 & 0.837 & 0.402 \\
STTR & 0.052 & 0.024 & 2.106 & $0.035^{* *}$ \\
Weighted statistics & & & & \\
$R^{2}{ }^{*}$ & 0.193 & & & \\
Adjusted $R^{2}{ }^{2}$ & 0.181 & & & \\
F-value & 16.93 & & & \\
sig(F-value) & 0.000 & & & \\
Observations & 360 & & & \\
Cross sections included & 12 & & & \\
Effects specification & & & & \\
Cross-sectional random & 22.78 & 0.465 & & \\
Idiosyncratic random & 24.41 & 0.534 & & \\
\hline
\end{tabular}

\section{Endogeneity test}

The correlation between an error term and variables creates an endogeneity problem, as can be evident in omitted variable bias, autocorrelated errors, and measurement errors. Endogeneity is an issue in scientific studies to check this clearly, as $O_{1}$ can be viewed as endogenous. This is presented by two independent variables, $Z$ and $P$. The main endogeneity model is as follows:

$$
Y=\varphi(O, P)-G
$$

where $G \geq 0$ is a measure of inefficiency. The parametric approaches consistent with $(Z$ and $P$ are independent, and $\psi$ is strictly monotone). To support $(X, Y)$, we should define $G$ as an exogenous variable. If we ignore $P$ as a latent variable, the endogeneity issue is presented. If we define the unconditional (to $P$ ) frontier as usual by $\phi(x)=\sup \{y|F Y| X(y \mid X \leq x)<1\}$, we can write the equation as follows:

$$
Y=\phi(X)-\tilde{u}
$$

The support of $\tilde{v}$ in the first model depends on $P$ and $X^{-1}$, which introduces the endogeneity issue. Endogeneity is a problem because its support depends on $X^{-1}$, but the distribution of $\tilde{v}$ does not depend on $X^{-1}$. Table 8 describes the endogeneity test and the results of the estimates of the variables. Furthermore, the Wald test was run to confirm the results and make them more robust; hence, the endogeneity issue was not present in the current study.

\section{Heteroskedasticity, normality, and variance inflation factors}

The data were distributed normally, and the null hypothesis was accepted based on the Jarque-Bera test. As presented in Table 9, the value of significance (two tailed) is 0.564 more than 0.05. Furthermore, Table 9 shows that the variance inflation factor (VIF) of all of the variables is less than 10 among the independent variables, and no variables have a tolerance value of less than 0.10 , which indicates the absence of multicollinearity among the variables. Since the significant value in

Table 7 Test cross-sectional random effects. Source: Software of E-views 10 output

\begin{tabular}{ll}
\hline Correlated random effects-Hausman test & \\
\hline Cross-sectional random & \\
\hline Chi-Sq. value & 8.516 \\
Chi-Sq. df & 5 \\
sig & 0.130 \\
\hline
\end{tabular}


Table 8 Endogeneity test. Source: Software of E-views 10 output. The dependent variable is the DCF. Method: Panel Least Squares

\begin{tabular}{|c|c|c|c|c|}
\hline Variables & Coefficient & Std. error & $t$-value & Sig \\
\hline RES_SMC & 0.042 & 0.088 & 0.479 & 0.631 \\
\hline FDINI & -0.099 & 0.117 & -0.853 & 0.394 \\
\hline GDPPG & -2.055 & 1.143 & -1.796 & 0.073 \\
\hline STTR & 0.027 & 0.028 & 0.972 & 0.331 \\
\hline CPI & 0.269 & 1.322 & 0.203 & 0.838 \\
\hline C & 144.0 & 4.765 & 30.21 & 0.000 \\
\hline$R^{2}$ & 0.760 & & & \\
\hline \multirow[t]{2}{*}{ Adjusted $R^{2}$} & 0.726 & & & \\
\hline & Value & df & Probability & \\
\hline \multicolumn{5}{|c|}{ Wald test: null hypothesis: C $(1)=0$} \\
\hline$t$-value & 0.479 & 314 & 0.631 & \\
\hline F-value & 0.230 & $(1,314)$ & 0.631 & \\
\hline $\mathrm{Chi}^{2}$ & 0.230 & 1 & 0.631 & \\
\hline RES_FDINI & -0.083 & 0.125 & -0.666 & 0.505 \\
\hline SMC & 0.049 & 0.085 & 0.577 & 0.564 \\
\hline GDPPG & -2.167 & 1.132 & -1.913 & 0.056 \\
\hline STTR & 0.032 & 0.026 & 1.205 & 0.228 \\
\hline $\mathrm{CPI}$ & 0.032 & 1.358 & 0.023 & 0.981 \\
\hline C & 140.3 & 7.152 & 19.61 & 0.000 \\
\hline$R^{-2}$ & 0.760 & & & \\
\hline Adjusted $R^{2}$ & 0.726 & & & \\
\hline \multicolumn{5}{|c|}{ Wald test: null hypothesis: C (1) $=0$} \\
\hline$t$-value & -0.666 & 314 & 0.505 & \\
\hline F-value & 0.444 & $(1,314)$ & 0.505 & \\
\hline $\mathrm{Chi}^{2}$ & 0.444 & 1 & 0.504 & \\
\hline RES_STTR & 0.032 & 0.026 & 1.210 & 0.227 \\
\hline FDINI & -0.082 & 0.125 & -0.658 & 0.511 \\
\hline SMC & 0.028 & 0.089 & 0.317 & 0.751 \\
\hline GDPPG & -2.095 & 1.128 & -1.858 & 0.064 \\
\hline $\mathrm{CPI}$ & 0.141 & 1.360 & 0.103 & 0.917 \\
\hline C & 143.9 & 7.499 & 19.19 & 0.000 \\
\hline$R^{2}$ & 0.760 & & & \\
\hline Adjusted $R^{2}$ & 0.7265 & & & \\
\hline \multicolumn{5}{|c|}{ Wald test: null hypothesis: $C(1)=0$} \\
\hline$t$-value & 1.210 & 314 & 0.227 & \\
\hline F-value & 1.464 & $(1,314)$ & 0.227 & \\
\hline $\mathrm{Chi}^{2}$ & 1.464 & 1 & 0.226 & \\
\hline RES_CPI & 0.101 & 1.358 & 0.074 & 0.940 \\
\hline STTR & 0.032 & 0.026 & 1.208 & 0.227 \\
\hline FDINI & -0.081 & 0.127 & -0.635 & 0.525 \\
\hline SMC & 0.044 & 0.086 & 0.516 & 0.606 \\
\hline GDPPG & -2.195 & 1.017 & -2.157 & 0.031 \\
\hline C & 141.1 & 7.118 & 19.83 & 0.000 \\
\hline$R^{-2}$ & 0.760 & & & \\
\hline Adjusted $R^{2}$ & 0.726 & & & \\
\hline \multicolumn{5}{|c|}{ Wald test: null hypothesis: C (1) $=0$} \\
\hline$t$-value & 0.074 & 314 & 0.940 & \\
\hline F-value & 0.005 & $(1,314)$ & 0.940 & \\
\hline $\mathrm{Chi}^{2}{ }^{2}$ & 0.005 & 1 & 0.940 & \\
\hline
\end{tabular}


Table 8 (continued)

\begin{tabular}{|c|c|c|c|c|}
\hline & Value & df & Probability & \\
\hline RES_GDPPG & -2.177 & 1.131 & -1.923 & 0.055 \\
\hline SMC & 0.016 & 0.088 & 0.184 & 0.853 \\
\hline FDINI & -0.078 & 0.125 & -0.626 & 0.531 \\
\hline STTR & 0.026 & 0.026 & 1.010 & 0.312 \\
\hline CPI & 0.389 & 1.282 & 0.303 & 0.761 \\
\hline C & 139.4 & 7.189 & 19.39 & 0.000 \\
\hline$R^{-2}$ & 0.760 & & & \\
\hline Adjusted $R^{2}$ & 0.726 & & & \\
\hline \multicolumn{5}{|c|}{ Wald test: null hypothesis: C (1) $=0$} \\
\hline$t$-value & -1.923 & 314 & 0.055 & \\
\hline F-value & 3.699 & $(1,314)$ & 0.055 & \\
\hline $\mathrm{Chi}^{2}$ & 3.699 & 1 & 0.054 & \\
\hline
\end{tabular}

this study is more than 0.05 , this means that there is no heteroskedasticity in the residual of the error correction model (ECM), and the coefficient estimation is efficient, unbiased, and consistent. In other words, ECM did not differ across the independent variable values.

\section{Quantile regression ( $\operatorname{tau}=0.10,0.20,0.30,0.40$, and 0.50 )}

This test was used to check the different levels in the distribution, as shown in Table 10. Hence, the current study re-estimated the model at different percentiles $(0.10$, $0.20,0.30,0.40$, and 0.50).

SMC, FDINI, and STTR had positive and significant effects on the DCF at the 0.10 percentile. One percent increases in SMC, FDINI, and STTR increased the DCF by $0.290,0.325$, and 0.083 , respectively, at the 0.10 percentile. While CPI had a negative and insignificant effect on the DCF at the 0.10 percentile, GDPPG had a negative and significant effect on the DCF at the 0.10 percentile.
One percent increases in CPI and GDPPG decreased the DCF by 0.373 and 4.708 , respectively.

SMC and STTR had positive and significant effects on the DCF at the 0.20 percentile. FDINI had a positive and insignificant effect on the DCF at the 0.20 percentile. One percent increases in SMC, FDINI, and STTR increased the DCF by $0.246,0.225$, and 0.050 , respectively, at the 0.20 percentile. CPI and GDPPG had negative and significant effects on the DCF at the 0.20 percentile. One percent increases in CPI and GDPPG decreased the DCF by 1.489 and 3.870 , respectively, at the 0.20 percentile.

SMC and STTR had positive and significant effects on the DCF at the 0.30 percentile. One percent increases in SMC and STTR increased the DCF by 0.233 and 0.053 , respectively, at the 0.30 percentile. FDINI had a negative and insignificant effect on the DCF at the 0.30 percentile. A $1 \%$ increase in FDINI decreased the DCF by 0.021 at the 0.30 percentile. CPI and GDPPG had negative and

Table 9 Heteroskedasticity, normality, variance inflation factors. Source: Software of E-views 10 output

\begin{tabular}{|c|c|c|c|}
\hline \multicolumn{4}{|c|}{ Heteroskedasticity test-white } \\
\hline F-value & 1.5431 & Sig $F(20,339)$ & 0.0650 \\
\hline \multirow[t]{2}{*}{$\mathrm{Obs}^{*} R^{2}$} & 30.039 & Sig. $\operatorname{Chi}^{2}(20)$ & 0.0692 \\
\hline & & Tolerance & VIF \\
\hline \multicolumn{4}{|c|}{ Variance inflation factors } \\
\hline SMC & & 0.902 & 1.107 \\
\hline FDINI & & 0.971 & 1.029 \\
\hline GDPPG & & 0.988 & 1.011 \\
\hline STTR & & 0.979 & 1.020 \\
\hline $\mathrm{CPI}$ & & 0.925 & 1.080 \\
\hline \multicolumn{4}{|c|}{ Normality } \\
\hline \multicolumn{4}{|c|}{$\begin{array}{l}\text { Normality test-J-B test value (sig-value) } 1.142 \text { (0.564) } \\
\text { Ho: Residuals are normal }\end{array}$} \\
\hline
\end{tabular}


Table 10 Quantile Regression (tau $=0.1,20,30,40,50$ ). Source: Software of E-views 10 output

\begin{tabular}{|c|c|c|c|c|}
\hline Variable & Coefficient & Std. error & $t$-value & Sig \\
\hline \multicolumn{5}{|c|}{ Method: quantile regression (tau $=0.1$ ) } \\
\hline C & 80.43 & 6.219 & 12.93 & 0.000 \\
\hline SMC & 0.290 & 0.040 & 7.209 & 0.000 \\
\hline FDINI & 0.325 & 0.184 & 1.765 & 0.078 \\
\hline GDPPG & -4.708 & 1.032 & -4.559 & 0.000 \\
\hline STTR & 0.083 & 0.017 & 4.749 & 0.000 \\
\hline $\mathrm{CPI}$ & -0.373 & 0.437 & -0.855 & 0.392 \\
\hline Pseudo- $R^{2}{ }^{2}$ & 0.126 & & & \\
\hline Quasi-LR value & 42.18 & & & \\
\hline sig(Quasi-LR stat) & 0.000 & & & \\
\hline \multicolumn{5}{|c|}{ Method: quantile regression ( $\operatorname{tau}=0.2$ ) } \\
\hline C & 101.5 & 4.800 & 21.15 & 0.000 \\
\hline SMC & 0.246 & 0.030 & 7.971 & 0.000 \\
\hline FDINI & 0.225 & 0.177 & 1.267 & 0.205 \\
\hline GDPPG & -3.870 & 0.781 & -4.949 & 0.000 \\
\hline STTR & 0.050 & 0.017 & 2.907 & 0.003 \\
\hline CPI & -1.489 & 0.492 & -3.023 & 0.002 \\
\hline Pseudo- $R^{2}{ }^{2}$ & 0.108 & & & \\
\hline Quasi-LR value & 47.13 & & & \\
\hline sig(Quasi-LR stat) & 0.000 & & & \\
\hline \multicolumn{5}{|c|}{ Method: quantile regression ( $\operatorname{tau}=0.3$ ) } \\
\hline C & 112.7 & 3.909 & 28.84 & 0.000 \\
\hline SMC & 0.233 & 0.027 & 8.412 & 0.000 \\
\hline FDINI & -0.021 & 0.242 & -0.089 & 0.928 \\
\hline GDPPG & -3.568 & 0.903 & -3.947 & 0.000 \\
\hline STTR & 0.053 & 0.026 & 2.016 & 0.044 \\
\hline $\mathrm{CPI}$ & -1.758 & 0.461 & -3.807 & 0.000 \\
\hline Pseudo- $R^{2}{ }^{2}$ & 0.116 & & & \\
\hline Quasi-LR value & 61.51 & & & \\
\hline sig(Quasi-LR stat) & 0.000 & & & \\
\hline \multicolumn{5}{|c|}{ Method: quantile regression (tau $=0.4$ ) } \\
\hline C & 120.9 & 5.471 & 22.10 & 0.000 \\
\hline SMC & 0.203 & 0.031 & 6.545 & 0.000 \\
\hline FDINI & 0.134 & 0.262 & 0.512 & 0.608 \\
\hline GDPPG & -3.573 & 0.968 & -3.690 & 0.000 \\
\hline STTR & 0.088 & 0.074 & 1.178 & 0.239 \\
\hline CPI & -1.872 & 0.510 & -3.669 & 0.000 \\
\hline Pseudo- $R^{2}$ & 0.129 & & & \\
\hline Quasi-LR value & 73.74 & & & \\
\hline sig (Quasi-LR stat) & 0.000 & & & \\
\hline \multicolumn{5}{|c|}{ Method: quantile regression (tau $=0.5$ ) (median) } \\
\hline C & 123.3 & 5.511 & 22.37 & 0.000 \\
\hline SMC & 0.213 & 0.034 & 6.142 & 0.000 \\
\hline FDINI & 0.342 & 0.256 & 1.332 & 0.183 \\
\hline GDPPG & -2.214 & 1.188 & -1.862 & 0.063 \\
\hline STTR & 0.088 & 0.072 & 1.215 & 0.225 \\
\hline CPI & -1.949 & 0.542 & -3.595 & 0.000 \\
\hline Pseudo- $R^{-2}$ & 0.132 & & & \\
\hline Quasi-LR value & 74.09 & & & \\
\hline
\end{tabular}

Table 10 (continued)

\begin{tabular}{lcccc}
\hline Variable & Coefficient & Std. error & $\boldsymbol{t}$-value & Sig \\
\hline sig(Quasi-LR stat) & 0.000 & & \\
\hline
\end{tabular}

significant effects on the DCF, respectively, at the 0.30 percentile. One percent increases in CPI and GDPPG decreased the DCF by 1.758 and 3.568, respectively, at the 0.30 percentile.

SMC had a positive and significant effect on the DCF at the 0.40 percentile. A $1 \%$ increase in SMC increased the DCF by 0.203 at the 0.40 percentile. FDINI and STTR had positive and insignificant effects on the DCF, respectively, at the 0.40 percentile. One percent increases in FDINI and STTR increased the DCF by 0.134 and 0.088 , respectively, at the 0.40 percentile. CPI and GDPPG had negative and significant effects on the DCF at the 0.40 percentile. One percent increases in CPI and GDPPG decreased the DCF by 1.872 and 3.573 , respectively, at the 0.40 percentile.

SMC had a positive and significant effect on the DCF at the 0.50 percentile. A $1 \%$ increase in SMC increased the DCF by 0.213 at the 0.50 percentile. FDINI and STTR had positive and insignificant effects on the DCF at the 0.50 percentile. One percent increases in FDINI and STTR increased the DCF by 0.342 and 0.088 at the 0.50 percentile. CPI and GDPPG had a negative and significant effect on the DCF at the 0.50 percentile. One percent increases in CPI and GDPPG decreased the DCF by 1.949 and 2.214, respectively, at the 0.50 percentile.

These results are consistent with Barro [8] and Babajide et al. [9], who indicated a strong stock market evaluation performance on financial growth, as well as Karabiyık and ve Taşkın, [35], who mentioned that strong bank assets affect financial development. The negative relationship between CPI and financial growth is consistent with Fama [27]. Furthermore, local investment enhances financial growth [52]. Mishra et al. [44] indicated that foreign investment funds positively contribute to local financial funds for economic growth, which is consistent with the current results. An investment decision is sensitive if borrowing is difficult and saving is at its lowest level; this affects investments in financial markets, which negatively affects economic growth [1].

\section{Pooled mean group}

Table 11 shows the results of pooled mean group (PMG) dynamic panel data test [63, 64]. PMG is an appropriate efficient estimator because of homogeneity assumptions as well as the model used different orders of cointegration. PMG was to determine the long- and short-run estimations between the variables of current model. The 
Table 11 Pooled mean group

\begin{tabular}{|c|c|c|c|c|c|}
\hline \multicolumn{3}{|c|}{ Long-run equation } & \multicolumn{3}{|c|}{ Short-run equation } \\
\hline Variable & Coefficient & Std. error & Variable & Coefficient & Std. error \\
\hline SMC & $0.489^{* * *}$ & 0.099 & COINTEQ01 & $-0.178^{* *}$ & 0.075 \\
\hline GDPPG & $-6.302^{* * *}$ & 1.281 & $\mathrm{D}(\mathrm{DCF}(-1))$ & $0.209^{*}$ & 0.121 \\
\hline $\mathrm{CPI}$ & $-6.000^{* * *}$ & 2.014 & $\mathrm{D}(\mathrm{DCF}(-2))$ & 0.173 & 0.136 \\
\hline FDINI & $-1.021^{* * *}$ & 0.188 & $\mathrm{D}(\mathrm{SMC})$ & -0.028 & 0.121 \\
\hline \multirow[t]{15}{*}{ STTR } & $0.218^{* * *}$ & 0.040 & $\mathrm{D}(\mathrm{SMC}(-1))$ & -0.147 & 0.146 \\
\hline & & & $\mathrm{D}(\mathrm{SMC}(-2))$ & 0.064 & 0.162 \\
\hline & & & $\mathrm{D}(\mathrm{GDPPG})$ & $1.366^{*}$ & 0.757 \\
\hline & & & $\mathrm{D}(\mathrm{GDPPG}(-1))$ & 2.688 & 2.007 \\
\hline & & & $\mathrm{D}(\mathrm{GDPPG}(-2))$ & 0.025 & 1.365 \\
\hline & & & $\mathrm{D}(\mathrm{CPI})$ & -3.573 & 2.158 \\
\hline & & & $\mathrm{D}(\mathrm{CPI}(-1))$ & 2.153 & 3.076 \\
\hline & & & $\mathrm{D}(\mathrm{CPI}(-2))$ & -2.306 & 2.177 \\
\hline & & & $\mathrm{D}(\mathrm{FDINI})$ & 1.938 & 1.452 \\
\hline & & & $\mathrm{D}(\mathrm{FDINI}(-1))$ & 1.168 & 1.212 \\
\hline & & & $\mathrm{D}(\mathrm{FDINI}(-2))$ & 1.792 & 1.286 \\
\hline & & & $\mathrm{D}(\mathrm{STTR})$ & -0.794 & 0.730 \\
\hline & & & $\mathrm{D}(\operatorname{STTR}(-1))$ & -0.445 & 0.341 \\
\hline & & & $\mathrm{D}(\operatorname{STTR}(-2))$ & 0.182 & 0.177 \\
\hline & & & C & $20.66^{* *}$ & 9.931 \\
\hline
\end{tabular}

The dependent variable is D(DCF), at lags 3 (Fixed). SMC, GDPPG, CPI FDINI, and STTR. Standard errors in parentheses ${ }^{* * *} p<0.01,{ }^{* *} p<0.05,{ }^{*} p<0.1$, in all the models of the current study

long-run estimation in the European countries showed a significant negative relationship between GDPPG, CPI, FDINI, and DCF, while other variables of study showed a significant positive relationship between SMC, STTR, and DC. These results confirm the previous results of all estimators. The short-run estimation showed that COINTEQ01 was significant and negative. Furthermore, to increase robustness, the study used cross-sectional short-run coefficient of ARDL in all European countries separately in Tables 12 and 13. The short-run estimation showed that COINTEQ01 was significant and negative in all countries except Netherlands, Switzerland and Austria was significant and positive.

\section{Conclusions}

Financial crises have encouraged many countries to think about the financial systems and laws that govern financial markets and examine the composition of investment portfolios. This study aimed to identify the theoretical and practical relationship between the value of stock markets and financial development; this information can indicate which financial channels and tools affect the economic outlook and which are affected by companies and industry sectors.

Understanding finance is important for the pursuit of growth, and these dynamic interactions are important in developing financial systems and economic growth. The important question is whether and industry is only concerned with financing. In other words, it is important to determine whether there is empirical evidence to explain how an industry tracks financing. This paper focused on the impact of stock market capitalisation on the financial growth of Western European between 1989 and 2018.

Through the literature review, we found that we still need constant attention and research on the relationship between the development of finance and economic growth, which considers technological innovation. The present findings are consistent with the fact that strengthening the growth frameworks and technical techniques of financial systems contributes to the development of financial markets and reflects positively on financial growth. The pooled least square findings in the present study indicate positive significant relationships between SMC, FDINI, and STTR and the DCF and financial growth and negative significant relationships between GDPPG and CPI and the DCF. The FE, RE, and PMG results were the same, indicating positive significant relationships between SMC and STTR and the DCF and financial growth, while the effect of FDINI on the DCF was positive and insignificant. Finally, there were negative significant relationships between GDPPG and CPI and the DCF. 


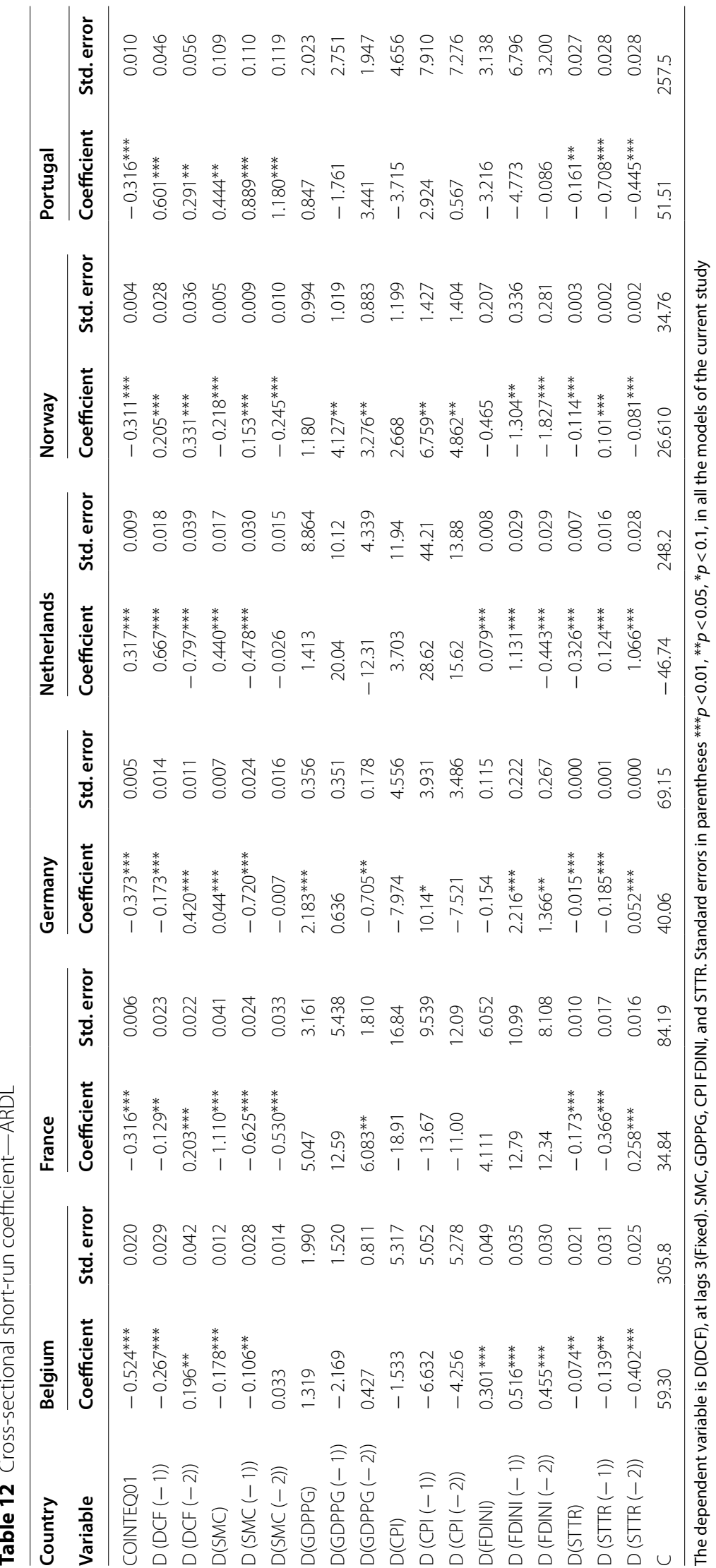




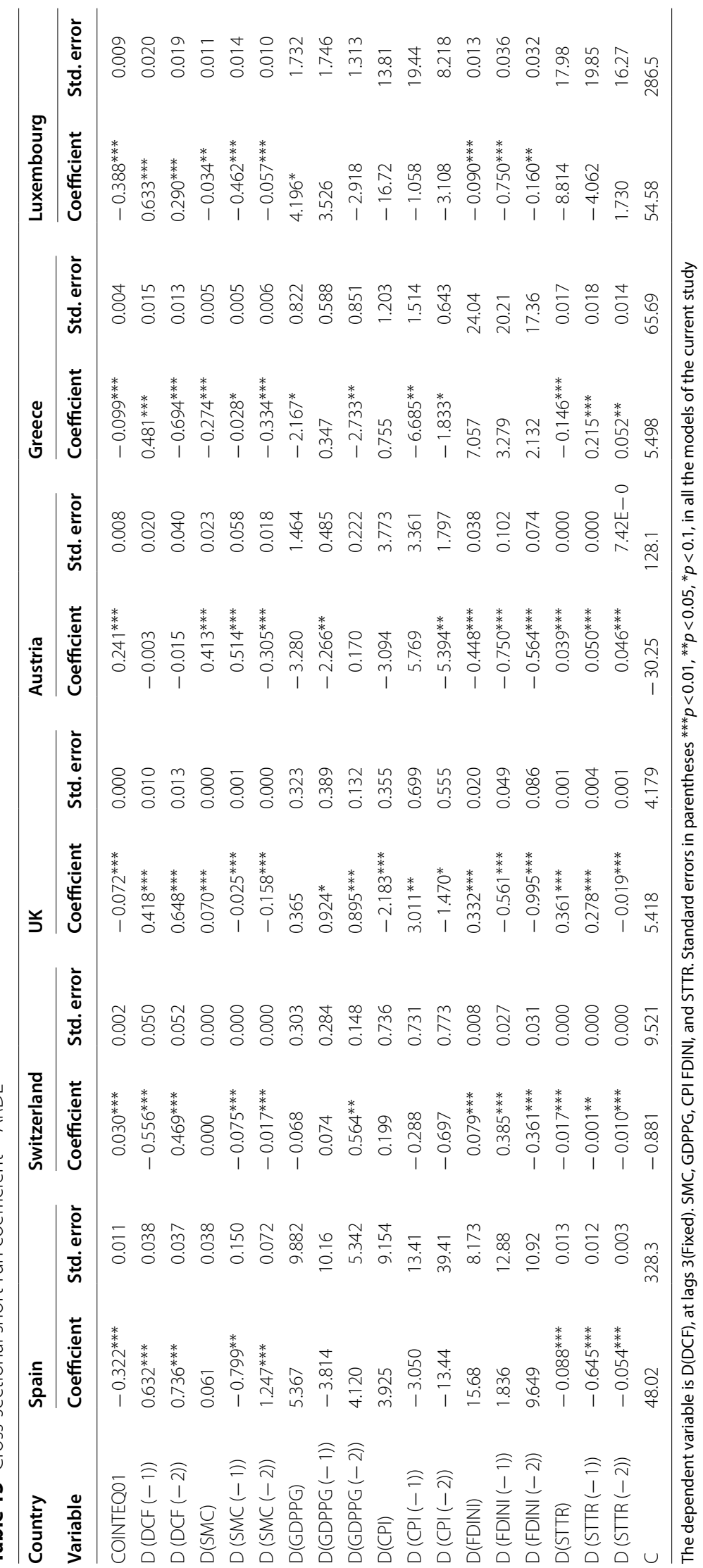


According to the quantile regression (tau $=0.10,0.20$, $0.30,0.40$, and 0.50 ), there were positive relationships between SMC and STTR and the DCF for all percentiles. There were negative relationships between GDDP and CPI and the DCF except at the 0.30 percentile; FDINI had a negative relationship with the DCF at the 0.30 percentile. Most variables were significant at a $1 \%$ significance level. CPI was insignificant at the 0.10 percentile, FDINI was insignificant at the $0.20,0.30,0.40$, and 0.50 percentiles, and STTR was insignificant at the 0.40 and 0.50 percentiles.

Many diagnostic tests were applied in the current study to explore heterogeneity and endogeneity issues and study heteroskedasticity, the variance inflation factor, and normality. Decision makers and policy makers must reallocate the types of financial risks and understand the role of financial intermediaries in financial markets in the process of financial growth in order to control different capacities and resources. This can be achieved through advanced financial systems that seek to develop the financial sector and reduce the obstacles facing companies in terms of external growth. Future studies need a more comprehensive understanding of the social and environmental indicators that can affect financial growth and should examine how legal regulations can play a prominent role in influencing financial growth and how macroeconomic policies shape financial sector operations.

\section{Appendix A}

Definitions of variables. Source: World Development Indicators (2018).

\begin{tabular}{|c|c|c|c|}
\hline Variable & Abbreviation & Measure & Definition \\
\hline $\begin{array}{l}\text { Stock market } \\
\text { capitalisation } \\
\text { proxy }\end{array}$ & SMC & $\begin{array}{l}\text { Stock market } \\
\text { capitalisa- } \\
\text { tion of listed } \\
\text { domestic } \\
\text { companies (\% } \\
\text { of GDP) }\end{array}$ & $\begin{array}{l}\text { SMC is the } \\
\text { market value } \\
\text { and includes } \\
\text { the number of } \\
\text { shares of com- } \\
\text { panies included } \\
\text { in their price }\end{array}$ \\
\hline $\begin{array}{l}\text { Financial growth } \\
\text { proxy }\end{array}$ & DCF & $\begin{array}{l}\text { Domestic credit } \\
\text { provided by } \\
\text { the financial } \\
\text { sector (\% of } \\
\text { GDP) }\end{array}$ & $\begin{array}{l}\text { DCF includes } \\
\text { one unit of } \\
\text { productivity } \\
\text { growth from any } \\
\text { industrial sector } \\
\text { in relation to the } \\
\text { total production } \\
\text { expressed in } \\
\text { adjusted infla- } \\
\text { tion }\end{array}$ \\
\hline GDP per capita & GDPPG & $\begin{array}{l}\text { GDP per } \\
\text { capita growth } \\
\text { (annual \%) }\end{array}$ & $\begin{array}{l}\text { GDPPG is the GDP } \\
\text { growth divided } \\
\text { by the size of } \\
\text { the country's } \\
\text { population }\end{array}$ \\
\hline
\end{tabular}

\begin{tabular}{|c|c|c|c|}
\hline Variable & Abbreviation & Measure & Definition \\
\hline $\begin{array}{l}\text { Foreign invest- } \\
\text { ment }\end{array}$ & FDINI & $\begin{array}{l}\text { Foreign direct } \\
\text { investment } \\
\text { net inflows (\% } \\
\text { of GDP) }\end{array}$ & $\begin{array}{l}\text { FDINI is the rate } \\
\text { of assets and } \\
\text { investments in } \\
\text { the local sector, } \\
\text { and it includes } \\
\text { all institutions } \\
\text { that participate } \\
\text { in building local } \\
\text { trade }\end{array}$ \\
\hline $\begin{array}{l}\text { Stocks traded } \\
\text { turnover }\end{array}$ & STTR & $\begin{array}{l}\text { Stocks traded, } \\
\text { turnover ratio } \\
\text { of domestic } \\
\text { shares (\%) }\end{array}$ & $\begin{array}{l}\text { STTR is the } \\
\text { amount of } \\
\text { liquidity per } \\
\text { share on the } \\
\text { number of } \\
\text { shares circulat- } \\
\text { ing in the } \\
\text { financial market. } \\
\text { A high circula- } \\
\text { tion of shares } \\
\text { indicates the } \\
\text { availability of } \\
\text { high liquidity }\end{array}$ \\
\hline Inflation & CPI & $\begin{array}{l}\text { Inflation, con- } \\
\text { sumer prices } \\
\text { (annual \%) }\end{array}$ & $\begin{array}{l}\text { CPI is the continu- } \\
\text { ous rise in the } \\
\text { general prices } \\
\text { of goods and } \\
\text { services in the } \\
\text { market }\end{array}$ \\
\hline
\end{tabular}

\section{Abbreviations}

SMC: Stock market capitalisation proxy; DCF: Financial growth proxy; GDPPG: GDP per capita; FDINI: Foreign investment; STTR: Stocks traded turnover; CPI: Inflation.

\section{Acknowledgements \\ Not applicable.}

\section{Authors' contributions}

I am the only author. I read and approved the final manuscript.

\section{Funding}

The author did not receive any fund for this study from either government or private sector.

\section{Availability of data and materials}

Source of datasets are available in World Bank Indicators from 1989 to 2018, at the link https://data.worldbank.org/. The Western European Countries selected form World Bank (2020 from: https://www.worldbank.org/en/country/weste rneurope. This submission submitted to Future Business Journal due to our topic is highly related in this journal. Furthermore, this journal has a high universal name around the world. This manuscript submitted to 'Future Business Journal', and that it is not currently under consideration elsewhere and the manuscript has not been published or submitted elsewhere.

\section{Declarations}

Competing interests

The author declares that they have no competing interests.

Received: 22 February 2021 Accepted: 31 July 2021

Published: 1 November 2021 


\section{References}

1. Aramburo S, Acevedo Y, Sonnemans J (2019) The influence of the strength of financial institutions and the investment-production delay on commodity price cycles: a framed field experiment with coffee farmers in Colombia. De Economist 167:347-358

2. Atje R, Jovanovic B (1993) Stock markets and development. Eur Econ Rev 37(2/3):632-640

3. Abbas SMA, Christensen J (2007) The role of domestic debt markets in economic growth: an empirical investigation for low-income countries and emerging markets. June. IMF working papers, pp 1-40

4. Araç A, Ozcan SK (2014) The causality between financial development and economic growth: the case of Turkey. J Econ Cooper Dev 35(3):171-198

5. Ayadi R, Arbak E, Ben-Naceur S, Groen WP (2015) Financial development, Bank efficiency and economic growth across the mediterranean. Mediterranean prospects

6. BeckT (2011) Finance and oil: is there a resource curse in financial development? Discussion Paper No. 2011-017 Center for Economic Research, Tilburg University.

7. Bijlsma M, Bonekamp J, Ewijk C, Haaijen F (2018) Funded pensions and economic growth. De Economist 166:337-362

8. Barro RJ, Ursua JF (2017) Stock-market crashes and depressions. Res Econ 71:384-398

9. Babajide A, Isola L, Somoye R (2016) Stock market response to economic growth and interest rate volatility: evidence from Nigeria. Int J Econ Financ Issues 6(1):354-360

10. Bijlsma M, Ewijk C, Haaijen F (2014) Economic growth and funded pension systems. Discussion paper, No: 279. CPB Netherland Bureau for Economic Policy Analysis.

11. Boubakari A, Jin D (2010) The role of stock market development in economic growth: evidence from some Euronext countries. Int J Financ Res 1(1):14-20

12. Büyükşalvarcı $A$ (2010) The effects of macroeconomics variables on stock returns: evidence from Turkey. Eur J Soc Sci 14(3):404-416

13. Cecchetti S, Kharroubi E (2012) Reassessing the impact of finance on growth. Working paper no. 381. Monetary and Economic Department, Bank for International Settlements

14. Checherita-Westphal C, Rother P (2012) The impact of high and growing debt on economic growth. An empirical investigation for the euro area. Eur Econ Rev 56(7):1392-1405

15. Clements B, Bhattacharya R, Nguyen TQ (2003) External debt, public investment, and growth in low-income countries. IMF working paper $03 / 249$

16. Coad A, Rao R (2006) Innovation and firm growth in high-tech sectors: a quantile regression approach, LEM Papers Series 2006/18, Laboratory of Economics and Management (LEM), Sant'Anna School of Advanced Studies, Pisa, Italy

17. Carpenter JN, Whitelaw RF (2017) The development of China's stock market and stakes for the global economy. Annu Rev Financ Econ 9:233-257

18. Coskun Y, Umit O (2016) Cointegration analysis between stock exchange and TL/FX saving deposits, gold, housing markets in Turkey. Bus Econ Res J 7(1):47-69

19. Demirguc-Kunt A, Levine R (2001) Financial structure and economic growth: a cross-country comparison of banks, markets, and development. MIT Press, Cambridge

20. Demirguc-Kunt A, Feyen E, Levine R (2012) The evolving importance of banks and securities markets. Working paper no. 18004. NBER, Cambridge

21. Devereux M, Smith GW (1994) International risk sharing and economic growth. Int Econ Rev 35(A):535-550

22. Dreger C, Reimers H-E (2013) Does Euro area membership affect the relation between GDP growth and public debt? J Macroecon 38(Part B):481-486

23. Evans R (1996) An analysis of criterion variable reliability in conjoint analysis. Percept Mot Skills 82(3):988-990

24. Fincke B, Greiner A (2015) Public debt and economic growth in emerging market economies. S Afr J Econ 83(3):357-370

25. Fink G, Haiss P, Hristoforova S (2003) Bond markets and economic growth. April. IEF working paper Nr. 49

26. Francis BB, Ofori E (2015) Political regimes and stock market development. Eurasian Econ Rev 5:111-137
27. Fama EF (1981) Stock returns, real activity, inflation and money. Am Econ Rev 71:545-565

28. Faisal F, Muhamad PM, Tursoy T (2016) Impact of economic growth, foreign direct investment and financial development on stock prices in China: empirical evidence from time series analysis. Int J Econ Financ 6(4):1998-2006

29. Gan C, Lee M, Yong HHA, Zhang J (2006) Macroeconomic variables and stock market interactions: New Zealand evidence. Invest Manag Financ Innovat 3(4):89-101

30. Heijdra B, Jiang Y, Mierau J (2019) The macroeconomic effects of longevity risk under private and public insurance and asymmetric information. De Economist 167:177-213

31. Harris RHF (1997) Stock markets and development: a re-assessment. Eur Econ Rev 41(1):139-146

32. International Monetary Fund (2012) The good, the bad, and the ugly: 100 years of dealing with public debt overhangs, in World economic outlook-coping with high debt and sluggish growth.

33. Johnston J, Dinardo J (1997) Econometric methods. ISBN-13: 978 0079131218. Rederived from https://www.scribd.com/doc/125990924/ Jack-Johnston-and-John-Dinardo-1997-Econometric-Methods on 01 May 2020.

34. Kaplan M (2008) The impact of stock market on real economic activity: evidence from Turkey. J Appl Sci 8:374-378

35. Karabıyık C, ve Tas, Kın FD (2016) Finansal kalkinma ve ekonomik büyüme ilis, kisi: brics Ülkeleri ve türkiye orne $€$ gi. Trakya university. J Soc Sci Inst 5(2):116-133

36. Kumar MS, Woo J (2010) Public debt and growth. IMF working paper number WP/10/174

37. Kurihara Y (2006) The relationship between exchange rate and stock prices during the quantitative easing policy in Japan. Int J Bus 11(4):375-386

38. Levine R, Zervos S (1998) Stock markets, banks, and economic growth. Am Econ Rev 88(3):537-558

39. Levin A, Lin CF (1992) Unit root test in panel data: asymptotic and finite sample properties. Discussion Paper, 92-93, Department of Economics, University of California at San Diego.

40. Levin A, Lin CF (1993) Unit root test in panel data: new results. Discussion paper, 93-56, Department of Economics, University of California at San Diego

41. Marques LM, Fuinhas JA, Marques AC (2013) Does the stock market cause economic growth? Portuguese evidence of economic regime change. Econ Model 32:316-324

42. McGowan CB (2008) A study of the relationship between stock market development and economic growth and development for 1994 to 2003. Int J Bus Econ Res J 7(5):79-86

43. Mahmudul A, Gazi U (2009) Relationship between interest rate and stock price: empirical evidence from developed and developing countries. Int J Bus Manag 4(3):43-51

44. Mishra PK, Das KB, Pradhan BB (2010) Foreign institutional investments and real economic growth in India: a causality test. Int Res J Financ Econ 41:215-222

45. Maysami RC, Koh TS (2000) A vector error correction model of the Singapore stock market. Int Rev Econ Financ 9:79-96

46. McKinnon RI (1973) Money and capital in economic development. Brookings Institution, Washington, DC

47. Mizen P, Tsoukas S (2014) What promotes greater use of the corporate bond market? A study of the issuance behaviour of firms in Asia? Oxf Econ Pap 66(1):227-253

48. Naceur B, Ghazouani S (2007) Stock markets, banks, and economic growth: empirical evidence from the MENA region. Res Int Bus Financ 21(2):297-315

49. Nordin S, Nordin N (2016) The impact of capital market on economic growth: a Malaysian outlook. Int J Econ Financ Issues 6(S7):259-265

50. Obstfeld M (1994) Risk-taking, global diversification, and growth. Am Econ Rev 54(5):1310-1329

51. Ologunde AO, Elumilade DO, Asaolu TO (2006) Stock market capitalization and interest rate in Nigeria: a time series analysis. Int Res J Financ Econ 4:154-167

52. Ong LL, Sy A (2004) The role of mature market mutual funds in emerging markets: myth or mayhem? IMF working paper. WP/04/133. July 
53. Panizza U, Presbitero AF (2013) Public debt and economic growth in advanced economies: a survey. Swiss J Econ Stat 149(2):175-204

54. Pradhan RP, Arvin MB, Bennett SE, Nair M, Hall JH (2016) Bond market development, economic growth and other macroeconomic determinants: panel VAR evidence. Asia-Pac Finan Mark 23:175-201. https://doi. org/10.1007/s10690-016-9214-x.28Y

55. Reinhart CM, Rogoff KS (2010) Growth in a time of debt. Working paper. No. 15639. NBER.

56. Rioja F, Valev N (2014) Stock markets, banks and the sources of economic growth in low- and high-income countries. J Econ Finance 38(2):302-320

57. Schclarek A (2004) Debt and economic growth in developing industrial countries. Mimeo. Working papers 2005:34, Lund University

58. Seven $\mathrm{U}$, Yetkiner $\mathrm{H}$ (2016) Financial intermediation and economic growth: does income matter? Econ Syst 40:39-58. https://doi.org/10. 1016/j.ecosys.2015.09.004

59. Singh S, Beetsma R (2018) Optimal monetary policy under sectoral interconnections. De Economist 166:309-336

60. Stiglitz JE (1985) Credit markets and the control of capital. J Money Credit Bank 17(2):133-152

61. Schumpeter JA (1911) The theory of economic development. Harvard Univ. Press, Cambridge

62. Thumrongvit P, Kim Y, Pyun CS (2013) Linking the missing market: the effect of bond markets on economic growth. Int Rev Econ Financ 27:529-541

63. Toda HY, Taku Y (1995) Statistical inference in vector autoregressions with possibly integrated processes. J Economet 66:225-250
64. Tugcu CT (2018) Panel data analysis in the energy-growth nexus (EGN). The economics and econometrics of the energy-growth nexus. Academic Press, Cambridge, pp 255-271

65. World Development Indicators (2018) Retrieved 01 Apr 2020. https:// databank.worldbank.org/source/worlddevelopment-indicato

66. World Bank (2020) Retrieved on 01 Apr 2020 from: https://www.world bank.org/en/country/westerneurope

67. Weissteiner T, Prettner K, Südekum J (2020) Three pillars of urbanization: migration, aging, and growth. De Economist 168:259-278

68. Wooldridge JM (2010) Econometric analysis of cross section and panel data, 2nd edn. MIT Press, Cambridge

69. Yu JS, Hassan MK, Sanchez B (2012) A re-examination of financial development, stock markets development and economic growth. Appl Econ 44:3479-3489

70. Zandberg E, Spierdijk L (2013) Funding of pensions and economic growth: are they really related. J Pens Econom Finance 12(2):151167

71. Zhou C (1996) Stock market fluctuations and the term structure (24 Jan 1996). SSRN: https://ssrn.com/abstract $=7277$

\section{Publisher's Note}

Springer Nature remains neutral with regard to jurisdictional claims in published maps and institutional affiliations.

\section{Submit your manuscript to a SpringerOpen ${ }^{\circ}$ journal and benefit from:}

- Convenient online submission

- Rigorous peer review

- Open access: articles freely available online

- High visibility within the field

- Retaining the copyright to your article

Submit your next manuscript at $\boldsymbol{\nabla}$ springeropen.com 